\title{
Denitrification and anaerobic ammonium oxidation in sediments: effects of microphytobenthos and $\mathrm{NO}_{3}^{-}$
}

\author{
Nils Risgaard-Petersen ${ }^{1, *}$, Rikke Louise Meyer ${ }^{2,3}$, Niels Peter Revsbech ${ }^{2}$ \\ ${ }^{1}$ National Environmental Research Institute, Department of Marine Ecology, Vejlsøvej 25, 8600 Silkeborg, Denmark \\ ${ }^{2}$ Department of Biological Sciences, University of Aarhus, bd 540, 8000 Århus C, Denmark \\ ${ }^{3}$ Present address: University of Queensland, Advanced Wastewater Management Center, Research Road, Building 64A, \\ St. Lucia, Brisbane, Queensland 4072, Australia
}

\begin{abstract}
Microphytobenthos (MPB) regulate nitrogen fluxes across the sediment-water interface in shallow coastal and estuarine environments, where the water-phase concentrations exhibit pronounced variations in time and space. The impact of MPB and N-availability on anaerobic ammonium oxidation (anammox) and denitrification was studied in experimental microcosms using a combination of ${ }^{15} \mathrm{~N}$ isotope and microsensor techniques $\left(\mathrm{NO}_{3}{ }^{-}+\mathrm{NO}_{2}{ }^{-}\right.$and $\left.\mathrm{O}_{2}\right)$. The presence of MPB at low water-column $\mathrm{NO}_{3}{ }^{-}$concentrations led to an $85 \%$ reduction in the capacity of the sediments for performing the anammox reaction within a $3 \mathrm{wk}$ period, but did not affect the denitrification potential. The presence of MPB also had a significant impact on both $\mathrm{O}_{2}$ and $\mathrm{NO}_{3}{ }^{-}+\mathrm{NO}_{2}{ }^{-}$ $\left(\mathrm{NO}_{\mathrm{x}}{ }^{-}\right)$concentrations in the sediment. At low $\mathrm{NO}_{3}{ }^{-}$concentrations, $\mathrm{NO}_{\mathrm{x}}{ }^{-}$was almost depleted in the alga-colonized sediments within 2 wk of incubation, due to assimilation and inhibition of nitrification. The depth distribution of $\mathrm{O}_{2}$ displayed significant variations during the light-dark cycles, leading to periodical $\mathrm{O}_{2}$ exposure of sediment strata that may harbor the anammox process. A sustained high anammox potential in sediments where MPB was allowed to colonize in the presence of $600 \mu \mathrm{M} \mathrm{NO}_{3}{ }^{-}$in the overlying water indicated that a steady supply of $\mathrm{NO}_{\mathrm{x}}{ }^{-}$and not protection from $\mathrm{O}_{2}$ exposure was the vital factor for maintenance of anammox capacity. In this case, $\mathrm{NO}_{\mathrm{x}}{ }^{-}$ penetrated approximately $9 \mathrm{~mm}$ into the sediment. We therefore suggest that a continuous supply of $\mathrm{NO}_{\mathrm{x}}{ }^{-}$to the anoxic sediment layers is the key factor for the presence of anammox in marine sediments. On the basis of these results, we suggest that anammox is of very limited significance in environments that periodically experience N-limitation and that occurrence of high rates of anammox in coastal sediments is limited to estuaries with permanently high concentrations of $\mathrm{NO}_{\mathrm{x}}{ }^{-}$in the water column.
\end{abstract}

KEY WORDS: Anammox $\cdot$ Benthic microalgae $\cdot$ Biosensor

Resale or republication not permitted without written consent of the publisher

\section{INTRODUCTION}

Anammox, the anaerobic oxidation of $\mathrm{NH}_{4}{ }^{+}$to $\mathrm{N}_{2}$ with $\mathrm{NO}_{2}^{-}$(Strous et al. 1999b), has recently been recognized as a significant contributor to $\mathrm{N}_{2}$ production in the marine environment along side pure $\mathrm{NO}_{3}{ }^{-}$- or $\mathrm{NO}_{2}{ }^{-}$-based $\mathrm{N}_{2}$ production (denitrification) (Thamdrup \& Dalsgaard 2002, Dalsgaard et al. 2003, Kuypers et al. 2003, Trimmer et al. 2003, Risgaard-Petersen et al. 2004a, Rysgaard \& Glud 2004, Rysgaard et al. 2004).
According to present knowledge, the anammox process is exclusively carried out by autotrophic, obligately anaerobic bacteria of the phylum Planctomycetes (Strous et al. 1999a, Schmidt et al. 2002, Kuypers et al. 2003, Schmid et al. 2003, Risgaard-Petersen et al. 2004a). Yet, the factors regulating the abundance of anammox bacteria, their activity and their contribution to bacterial $\mathrm{N}_{2}$ production in the marine environment are largely unknown. Knowledge about the physicochemical requirements of marine anammox bacteria is 
very limited at present, because these organisms have not yet been isolated and characterized and because studies of their biogeography are few and contain little information about their microenvironment. Although studies of enrichment cultures of anammox bacteria from activated sludge have provided insight into the ecophysiology of the genera Kuenenia and Brocadia (van de Graaf et al. 1996, Strous et al. 1997, 1999a), these bacteria are only distantly related to the marine anammox bacteria detected by molecular methods in the water column and sediments (Kuypers et al. 2003, Risgaard-Petersen et al. 2004a). Consequently, extrapolation from enrichment cultures to natural systems should be made with caution.

The occurrence of anammox and the relative significance of the process compared with denitrification have previously been investigated in sediment from 2 shallow-water estuaries: Randers Fjord and Norsminde Fjord, Denmark (Risgaard-Petersen et al. 2004a). This study demonstrated that the anammox process is not ubiquitous in marine sediments as it accounted for up to $24 \%$ of $\mathrm{N}_{2}$ production in the Randers Fjord sediment, but was absent in Norsminde Fjord. Microphytobenthos (MPB) were present in the sediment from both sites, but in Norsminde Fjord a combination of microphytobenthic assimilation and low $\mathrm{NO}_{3}^{-}$concentrations in the water column led to the absence of $\mathrm{NO}_{\mathrm{x}}{ }^{-}$in the anoxic sediment strata during summer. This was not the case in Randers Fjord due to higher water-column $\mathrm{NO}_{3}{ }^{-}$concentrations. It was hypothesized that MPB affected the presence of anammox by limiting the availability of $\mathrm{NO}_{3}{ }^{-}+\mathrm{NO}_{2}^{-}\left(\mathrm{NO}_{\mathrm{x}}^{-}\right)$in the anoxic sediment, which could explain why anammox was absent only in Norsminde Fjord. The fact that denitrification, in contrast to anammox, could be detected at both sites was taken as evidence that denitrifiers are less vulnerable to periodic $\mathrm{NO}_{\mathrm{x}}{ }^{-}$depletion because they are believed to be more metabolically versatile than anammox bacteria.

In the present study, we tested the hypothesis that sediments with periodic $\mathrm{NO}_{\mathrm{x}}^{-}$depletion within the anoxic layer are not able to sustain anammox activity, while there is no such detrimental effect on denitrification activity. Furthermore, we tested that benthic microalgae can contribute to that depletion when the $\mathrm{NO}_{\mathrm{x}}{ }^{-}$concentration in the overlying water is low. The hypothesis was tested in experimental sediment microcosms held under defined conditions of light and water-column $\mathrm{NO}_{\mathrm{x}}{ }^{-}$concentration. The microscale distribution of $\mathrm{NO}_{\mathrm{x}}{ }^{-}$in the sediment was measured with $\mathrm{NO}_{3}{ }^{-}$biosensors (Larsen et al. 1997), and anammox and denitrification capacity were determined in sediment slurries by use of ${ }^{15} \mathrm{~N}$ isotope techniques (Thamdrup \& Dalsgaard 2002).

\section{MATERIALS AND METHODS}

Experimental setup. Effects of MPB colonization and $\mathrm{NO}_{3}{ }^{-}$on porewater chemistry and on the ability of sediments to perform anammox and denitrification were addressed in 2 experimental rounds. The first round investigated the effect of algal colonization on the microscale distribution of $\mathrm{NO}_{\mathrm{x}}{ }^{-}$as well as the activity of nitrifying, denitrifying and anammox bacteria. In the second experimental round, we focused on the relationship between $\mathrm{NO}_{\mathrm{x}}{ }^{-}$availability and anammox by repeating the experiment with an additional series of MPB-colonized sediment cores incubated with excess $\mathrm{NO}_{\mathrm{x}}{ }^{-}$in the water column to ensure that the algae did not induce $\mathrm{NO}_{\mathrm{x}}^{-}$limitation.

All experiments were conducted with material from experimental microcosms. These were prepared from surface sediment (i.e. upper $5 \mathrm{~cm}$ ) collected at $1 \mathrm{~m}$ depth in Randers Fjord, Denmark, where a high capacity for anammox has previously been found (Risgaard-Petersen et al. 2004a). The sediment was sieved through a $1 \mathrm{~mm}$ mesh screen to remove large animals and shell fragments. Sediment cores were then made by adding sieved sediment to Plexiglas core tubes (i.d.: $50 \mathrm{~mm}$, height: $100 \mathrm{~mm}$ ). Black plastic was wrapped around the core tubes from the bottom of the tube to the sediment surface in order to prevent MPB colonization of the core walls.

In the first experimental round, the cores were divided into 2 groups: low-N alga-free sediments and low- $\mathrm{N}$ alga sediments ( $\mathrm{n}=6$ for each treatment). Both groups were transferred to aquaria with constantly aerated, filtered (1 $\mu \mathrm{m}$, Millipore) seawater mixed with tap water (1:1 vol/vol, salinity $10 \%$, corresponding to the in situ salinity). Nitrate was 5 to $10 \mu \mathrm{M}$. The low-N alga sediments were incubated in a transparent aquarium and were exposed to a 12:12 h light:dark cycle (irradiance: $200 \mu \mathrm{mol}$ photons $\mathrm{m}^{-2} \mathrm{~s}^{-1}$ ), in order to promote growth of MPB. Light was provided by $400 \mathrm{~W}$ greenhouse lamps (HPI-T+ Mercury, Phillips). The light level was selected within the range used by Dalsgaard (2003) (100 to $300 \mu \mathrm{mol}$ photons $\mathrm{m}^{-2} \mathrm{~s}^{-1}$ for the May to September period), when measuring denitrification and $\mathrm{N}$ fluxes at a shallow (75 cm deep) site in a Danish estuary. The low-N alga-free sediments were incubated in a darkened aquarium in order to prevent growth of MPB.

The second experimental round investigated impacts of MPB in the presence and absence of $\mathrm{NO}_{3}{ }^{-}$on porewater chemistry, anammox and denitrification. For this purpose the cores were divided into 3 groups: low-N alga-free sediments, low- $\mathrm{N}$ alga sediments and high-N alga sediments. The low-N alga-free and low$\mathrm{N}$ alga sediments were incubated as described above for the first experimental round, whereas the high-N alga sediments were incubated as the low-N alga sed- 
iments with the modification that the overlying water contained approximately $600 \mathrm{\mu M} \mathrm{NO}_{3}{ }^{-}$. Both experimental rounds were conducted at $19^{\circ} \mathrm{C}$. The temperature of the water in Randers Fjord ranges from 15 to $20^{\circ} \mathrm{C}$, as a monthly average in the period from May to September (Sømod et al. 2003). Water was renewed every 3 to $4 \mathrm{~d}$ to maintain a relatively stable chemistry.

Porewater profiles of $\mathrm{NO}_{\mathrm{x}}^{-}$and $\mathrm{O}_{2}$ were measured repeatedly (see next subsection) for a period of $4 \mathrm{wk}$ to monitor the availability of $\mathrm{NO}_{\mathrm{x}}{ }^{-}$in the anoxic sediment strata and to study the mechanisms controlling its availability. When pronounced differences in porewater chemistry among the different treatments were achieved, impacts on anammox and denitrification were studied.

Porewater profiles of $\mathbf{N O}_{\mathbf{x}}{ }^{-}$and $\mathbf{O}_{2}$. Porewater profiles of $\mathrm{NO}_{\mathrm{x}}{ }^{-}$and $\mathrm{O}_{2}$ were measured in all sediments using microsensors for $\mathrm{O}_{2}$ (Revsbech 1989) and biosensors for $\mathrm{NO}_{\mathrm{x}}^{-}$(Larsen et al. 1997). Profiles were measured at $19^{\circ} \mathrm{C}$ in low-N alga and alga-free sediments, as described by Meyer et al. (2001), after 1, 2 and 4 wk of incubation. The high-N sediments were only analyzed after 4 wk of incubation. Then, 3 to 5 replicate profiles were measured in all microsensor experiments. Oxygen and $\mathrm{NO}_{\mathrm{x}}{ }^{-}$were measured in the low-N and high-N alga cores in light and in darkness, whereas all profiles in the low- $\mathrm{N}$ alga-free sediment were measured in darkness. Light was provided by a halogen lamp (irradiance: $200 \mu \mathrm{mol}$ photons $\mathrm{m}^{-2} \mathrm{~s}^{-1}$ ).

Ammonium (1 mM) was added to the water above 1 low-N alga core after $2 \mathrm{wk}$ of incubation to investigate whether $\mathrm{NH}_{4}^{+}$limitation of nitrification caused an observed depletion of $\mathrm{NO}_{\mathrm{x}}{ }^{-}$in the sediment.

Profiles of $\mathrm{NO}_{\mathrm{x}}^{-}$production or consumption were obtained by modeling the experimental data using the numerical procedure described by Berg et al. (1998). The sediment diffusion coefficient used in the calculations was estimated from the sediment porosity and the free diffusion coefficients of $\mathrm{NO}_{3}{ }^{-}$and $\mathrm{O}_{2}$ at $19^{\circ} \mathrm{C}$ and a salinity of 10 (Broecker \& Peng 1974, Li \& Gregory 1974), as described by Iversen \& Jørgensen (1993).

Anammox and denitrification. In the first experimental round, we sought to confirm the presence of the anammox process in the sediment and to demonstrate that MPB affects anammox and denitrification capacity, by measuring the potential rates in low-N alga and low-N alga-free cores at the end of the $3 \mathrm{wk}$ incubation period. In the second experimental round, we addressed the manner in which MPB impacts the processes through $\mathrm{N}$-limitation by comparing the denitrification and anammox capacities in low-N alga and high-N alga sediments with the low-N alga-free sediments and with the initial capacities of the sediment prior to incubation in the microcosms.

Anammox and denitrification capacities were assessed with the ${ }^{15} \mathrm{~N}$ methodology devised by Tham- drup \& Dalsgaard (2002). The processes were measured in $\mathrm{O}_{2}$-free slurries (sediment:water ratio $=1: 5$ ) prepared in $6 \mathrm{ml}$ Exetainers, as described in RisgaardPetersen et al. (2004a), from sediment from the top $5 \mathrm{~mm}$ of the sediment cores. Slurries were preincubated for $24 \mathrm{~h}$ in order to eliminate background $\mathrm{NO}_{\mathrm{x}}{ }^{-}$ and $\mathrm{O}_{2}$. During the first experimental round, 4 different ${ }^{15} \mathrm{~N}-{ }^{14} \mathrm{~N}$ isotopic mixtures were added to the slurry incubations: (1) ${ }^{15} \mathrm{NO}_{3}{ }^{-}\left[{ }^{15} \mathrm{~N}\right.$-atom\%: 98.3], (2) ${ }^{15} \mathrm{NO}_{3}{ }^{-}+$ ${ }^{14} \mathrm{NH}_{4}{ }^{+}$, (3) ${ }^{15} \mathrm{NH}_{4}{ }^{+}\left[{ }^{15} \mathrm{~N}\right.$-atom\%: 99.6] and (4) ${ }^{15} \mathrm{NH}_{4}{ }^{+}+$ ${ }^{14} \mathrm{NO}_{3}{ }^{-}$. Experiments with $\mathrm{NH}_{4}^{+}$additions (Incubation 2) were performed as a check for $\mathrm{NH}_{4}{ }^{+}$limitation of the anammox process during the incubation.

Approximately $100 \mu \mathrm{l}$ of the $\mathrm{O}_{2}$-free isotopic mixtures was injected through the septum of the Exetainer using a Hamilton syringe. $\mathrm{NO}_{3}{ }^{-}$and $\mathrm{NH}_{4}{ }^{+}$were added to concentrations of about $100 \mu \mathrm{M}$. Incubations were stopped by the addition of $200 \mu \mathrm{l}$ of $8 \mathrm{M} \mathrm{ZnCl}_{2}$ to individual slurries at regular intervals within the $4 \mathrm{~h}$ incubation period. Water samples for $\mathrm{NH}_{4}{ }^{+}$analysis were collected from parallel series of ${ }^{15} \mathrm{NO}_{3}{ }^{-}$-amended samples at the end of the $4 \mathrm{~h}$ incubation period. The same procedure was applied in the second experimental round. However, slurries were amended with $200 \mu \mathrm{M}$ ${ }^{15} \mathrm{NO}_{3}{ }^{-}$and $200 \mu \mathrm{M} \mathrm{NH}_{4}{ }^{+}$in order to ensure that the anammox process was not $\mathrm{NH}_{4}{ }^{+}$-limited, and incubations with ${ }^{15} \mathrm{NH}_{4}{ }^{+}$(Incubations 3 and 4 ) were omitted. Two days before the measurements were performed, high-N alga cores were transferred to reservoirs with $<5 \mathrm{MM} \mathrm{NO}_{3}{ }^{-}$in order to reduce the sediment $\mathrm{NO}_{3}{ }^{-}$pool, as the presence of high amounts of $\mathrm{NO}_{3}{ }^{-}$could complicate interpretations of the results. Measurements of $\mathrm{NO}_{3}{ }^{-}$in $24 \mathrm{~h}$-preincubated slurries verified that $\mathrm{NO}_{3}{ }^{-}$ was below the detection limit prior to isotope addition.

Denitrification and anammox rates were calculated from the production of ${ }^{14} \mathrm{~N}^{15} \mathrm{~N}\left({ }^{29} \mathrm{~N}_{2}\right)$ and ${ }^{15} \mathrm{~N}^{15} \mathrm{~N}\left({ }^{30} \mathrm{~N}_{2}\right)$ in the ${ }^{15} \mathrm{NO}_{3}{ }^{-}$-amended slurries (1 and 2), as described by Thamdrup \& Dalsgaard (2002). Five time points were used to calculate the production rate for each replicate. Production of ${ }^{15} \mathrm{~N}$-labelled $\mathrm{N}_{2}$ in Incubation 4 and absence of ${ }^{15} \mathrm{~N}-\mathrm{N}_{2}$ production in Incubation 3 were taken as additional evidence for the presence of the anammox reaction (Thamdrup \& Dalsgaard 2002, Trimmer et al. 2003).

The abundance of ${ }^{29} \mathrm{~N}_{2}$ and ${ }^{30} \mathrm{~N}_{2}$ in the samples was measured by combined gas chromatography/mass spectrometry (RoboPrep-G+ in line with Tracermass, Europa Scientific), as described in Risgaard-Petersen \& Rysgaard (1995). Ammonium in the slurry water was determined automatically by the salicylate-hypochlorite method (Bower \& Holm-Hansen 1980) on a robotic sample processor (Tecan RSP-5051, Tecan AG) in line with a spectrophotometer (Shimadzu UV-1601). Nitrite was determined using the method described by Grasshoff et al. (1983). 


\section{RESULTS}

\section{Anammox and denitrification}

Data from anammox and denitrification measurements performed in the first experimental round are given in Table 1 . The presence of a capacity for anammox in both low-N alga and alga-free sediments was confirmed by lack of ${ }^{15} \mathrm{~N}-\mathrm{N}_{2}$ production in slurries incubated with only ${ }^{15} \mathrm{NH}_{4}{ }^{+}$and by significant ${ }^{29} \mathrm{~N}_{2}$ production in slurries amended with ${ }^{15} \mathrm{NH}_{4}{ }^{+}$and ${ }^{14} \mathrm{NO}_{3}^{-}$. Production of ${ }^{29} \mathrm{~N}_{2}$ in the latter series originated from the anammox reaction, and the fact that production rates of ${ }^{29} \mathrm{~N}_{2}$ in slurries from low-N alga-free sediments were twice as high as those in low- $\mathrm{N}$ alga sediments indicated that the anammox capacity was higher in the alga-free sediment. However, because concentrations of ${ }^{14} \mathrm{NH}_{4}{ }^{+}$and consequently the ${ }^{15} \mathrm{~N}$-atom $\%$ of the $\mathrm{NH}_{4}{ }^{+}$ substrate were not identical for the 2 treatments, rates are not directly comparable.

The difference in sediment anammox capacity was demonstrated by incubation with ${ }^{15} \mathrm{NO}_{3}{ }^{-}$and subsequent calculation of the actual anammox and denitrification rates (Table 1). Anammox rates measured in slurries prepared from the low- $\mathrm{N}$ alga sediment were approximately $10 \%$ of the rates obtained from low-N alga-free sediments. Although the $\mathrm{NH}_{4}{ }^{+}$concentration in the low-N alga slurries was lower than in the alga-free slurries $(13.5 \pm 7.8$ vs. $41.5 \pm 11 \mu \mathrm{M}$ at the end of the incubation), $\mathrm{NH}_{4}^{+}$limitation could be ruled out as a cause for the differences in anammox capacity. This was indicated by the observation that $\mathrm{NH}_{4}{ }^{+}$addition did not result in significant changes in rates in low-N alga or in alga-free sediment (Table 1, Student's $t$-test $\mathrm{p}>0.43)$. Ammonium in these samples was $84 \pm 4$ and $120 \pm 9 \mu \mathrm{M}$ in the alga and algafree samples, respectively. Nitrite increased from 1 to $10 \pm 0.7 \mu \mathrm{M}$ in the low- $\mathrm{N}$ alga slurries during the incubation and from 1 to $6.4 \pm 0.3 \mu \mathrm{M}$ in the low-N

Table 1. Rates of denitrification, anammox and ${ }^{29} \mathrm{~N}_{2}$ and ${ }^{30} \mathrm{~N}_{2}$ production measured in slurries based on subsamples from the low-N alga and low- $\mathrm{N}$ alga-free sediment using different combinations of $\mathrm{N}$ isotopes. SEM values are given in parentheses $(n=3)$. Data are from the first experimental series

\begin{tabular}{|lccc|}
\hline \multirow{2}{*}{ Amendment } & Parameter & \multicolumn{2}{c|}{ Rate $\left(\mathrm{nmol} \mathrm{cm}^{-3} \mathrm{~h}^{-1}\right)$} \\
& & Low-N alga & Low-N alga-free \\
& Denitrification & $121(11)$ & $113(11)$ \\
& Anammox & $1.25(0.47)$ & $10.11(1.12)$ \\
${ }^{15} \mathrm{NO}_{3}{ }^{-}$ & Denitrification & $96(12)$ & $120(25)$ \\
& Anammox & $2.02(0.53)$ & $8.57(1.91)$ \\
${ }^{15} \mathrm{NO}_{3}{ }^{-}+{ }^{14} \mathrm{NH}_{4}{ }^{+}$ & ${ }^{29} \mathrm{~N}_{2}$ & $-0.026(0.18)$ & $0(0.17)$ \\
& ${ }^{30} \mathrm{~N}_{2}$ & $0.06(0.011)$ & $0.027(0.067)$ \\
${ }^{15} \mathrm{NH}_{4}{ }^{+}$ & ${ }^{29} \mathrm{~N}_{2}$ & $3.10(0.63)$ & $6.40(0.24)$ \\
${ }^{15} \mathrm{NH}_{4}{ }^{+}+{ }^{14} \mathrm{NO}_{3}{ }^{-}$ & ${ }^{30} \mathrm{~N}_{2}$ & $0.12(0.03)$ & $0.24(0.01)$ \\
\hline
\end{tabular}
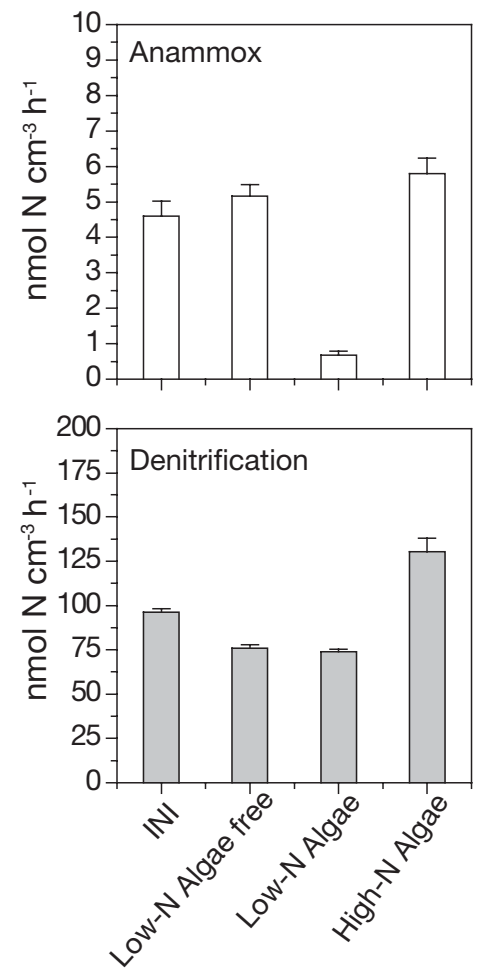

Fig. 1. Anammox and denitrification rates in the sediment as a function of treatment (INI, initial samples; low-N alga-free, dark incubation at 5 to $10 \mathrm{\mu M} \mathrm{NO}_{3}{ }^{-}$; low-N algae, light-dark incubation at 5 to $10 \mu \mathrm{M} \mathrm{NO}{ }_{3}^{-}$; high-N algae, light-dark incubation at approximately $600 \mu \mathrm{M} \mathrm{NO}_{3}{ }^{-}$). Except for the initial samples, all rates were measured after $3 \mathrm{wk}$ of incubation. Error bars represent SEM; data are from the second experimental series

alga-free slurries, which also excludes $\mathrm{NO}_{2}{ }^{-}$limitation as a cause of the reduced anammox rate measured in the low-N alga slurries. In contrast to anammox, the ability of the sediments to perform denitrification was similar in sediments with and without algae (Student's $t$-test, $\mathrm{p}=0.67$ ).

Similar differences between the low-N alga and alga-free sediments were obtained in the second experimental round (Fig. 1). The lowest capacity for anammox was observed in the low-N alga sediment (ANOVA, p $<0.001$, Scheffé's post hoc comparisons, $\alpha=0.05)$, where the anammox capacity had decreased by $85 \%$ during the 3 wk incubation period (Fig. 1). The anammox capacity did not, however, change significantly in the high-N alga sediments, and rates obtained in low-N alga-free cores and high- $\mathrm{N}$ alga cores at the end of the incubations were similar.

The denitrification capacity was similar in the low-N alga-free and low-N alga 
sediments, but higher in the high-N alga sediments (ANOVA, $\mathrm{p}<0.001$, Scheffé's post hoc comparisons, $\alpha=0.05$ ) at the end of the 3 wk incubation. In all low-N sediments (with and without algae), denitrification decreased by approximately $20 \%$ during the incubation period, whereas it increased by approximately $33 \%$ in the high-N sediment.

\section{Oxygen and $\mathrm{NO}_{\mathrm{x}}^{-}$porewater profiles in alga and alga-free sediments}

$\mathrm{O}_{2}$ and $\mathrm{NO}_{\mathrm{x}}{ }^{-}$porewater profiles in low-N alga and alga-free sediments measured after 1, 2 and 4 wk of incubation are shown in Fig. 2. After 1 wk of incubation, $\mathrm{NO}_{\mathrm{x}}{ }^{-}$ penetrated $>1 \mathrm{~mm}$ into the anoxic zone in both the low-N alga and alga-free sediments. For both types of sediment, aerobic $\mathrm{NO}_{\mathrm{x}}{ }^{-}$production (i.e. nitrification) was the major source of $\mathrm{NO}_{\mathrm{x}}^{-}$input to the anoxic zone. $\mathrm{NO}_{\mathrm{x}}{ }^{-}$production was highest in the low-N alga sediment, both during illumination and in darkness, facilitating a higher flux into the anoxic zone and higher rates of anaerobic $\mathrm{NO}_{\mathrm{x}}^{-}$consumption in this sediment (Fig. 2). The highest rate of $\mathrm{NO}_{\mathrm{x}}{ }^{-}$ production in this sediment was observed during illumination when net production of $\mathrm{NO}_{\mathrm{x}}{ }^{-}$occurred in a zone extending from a depth of $2 \mathrm{~mm}$ to the oxic/anoxic interface. Below and above this zone, net consumption of $\mathrm{NO}_{\mathrm{x}}{ }^{-}$was observed. The observed aerobic net consumption of $\mathrm{NO}_{\mathrm{x}}{ }^{-}$coincided with the $\mathrm{O}_{2}$ production zone and can be ascribed to microphytobenthic N-uptake. During darkness nitrification occurred in a $1.2 \mathrm{~mm}$ layer above the oxic/anoxic interface, and there was no indication of net consumption or production in the $1.2 \mathrm{~mm}$ surface layer that had been most photosynthetically active. Thus, consumption of $\mathrm{NO}_{\mathrm{x}}^{-}$ occurred exclusively in the adjacent anoxic zone. In the low-N alga-free sediment, $\mathrm{NO}_{\mathrm{x}}^{-}$production occurred in the entire oxic zone, maximum activity being located in the lower part of the zone.

After $2 \mathrm{wk}$ of incubation, there was no indication of net $\mathrm{NO}_{\mathrm{x}}{ }^{-}$production in the low-N alga sediment. $\mathrm{NO}_{\mathrm{x}}{ }^{-}$ was exclusively consumed in the oxic zone, both in the dark and during illumination, and, consequently, there was no $\mathrm{NO}_{\mathrm{x}}{ }^{-}$supply to the anoxic zone. In contrast, $\mathrm{NO}_{\mathrm{x}}{ }^{-}$production was preserved in low-N alga-free sediment, and $\mathrm{NO}_{\mathrm{x}}{ }^{-}$penetrated approximately $2 \mathrm{~mm}$

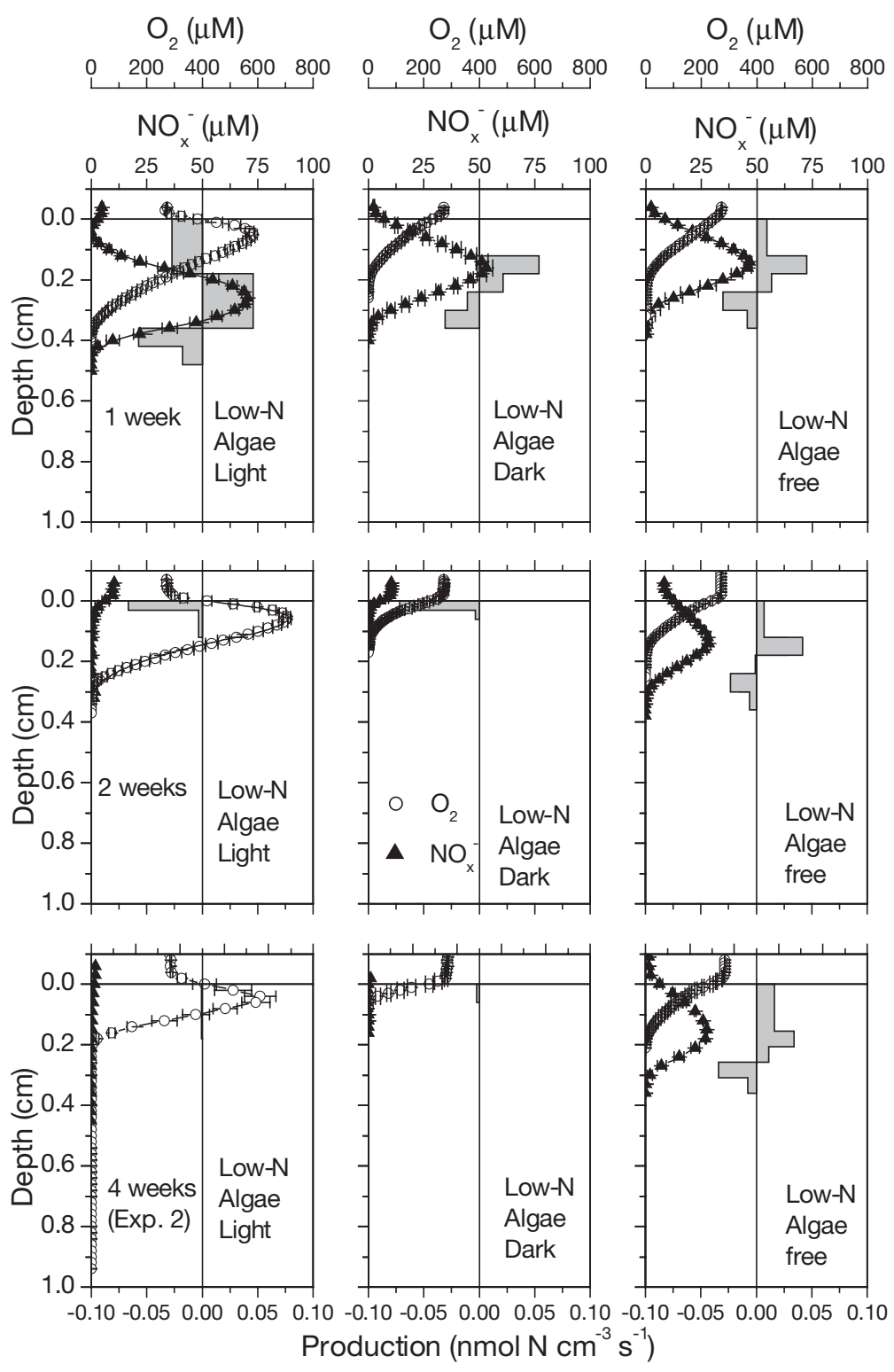

Fig. 2. Porewater profiles of $\mathrm{O}_{2}(\mathrm{O})$ and of $\mathrm{NO}_{\mathrm{x}}^{-}(\mathbf{\Lambda})$ and $\mathrm{NO}_{\mathrm{x}}^{-}$production profiles (gray boxes), measured in the low-N alga-free and low- $\mathrm{N}$ alga sediments after 1, 2 and $4 \mathrm{wk}$ of incubation. Line represents modeled profiles. Note that data from the 1 to $2 \mathrm{wk}$ periods are from Experimental Series 1, whereas data from the $4 \mathrm{wk}$ period are from Experimental Series 2. Error bars represent SEM

into the anoxic zone, where it was consumed. At this point, the mechanism of $\mathrm{NO}_{\mathrm{x}}{ }^{-}$limitation was tested through $\mathrm{NH}_{4}{ }^{+}$pulse additions (see next subsection).

The $\mathrm{NO}_{\mathrm{x}}^{-}$profiles in the low-N alga and alga-free sediments measured after 4 wk of incubation were very similar to profiles measured after $2 \mathrm{wk}$. The profiles obtained after 4 wk of incubation in the first and second experimental round were almost identical. Therefore, only data from the second experimental round are shown here. In the low- $\mathrm{N}$ alga sediment, $\mathrm{NO}_{\mathrm{x}}^{-}$was 


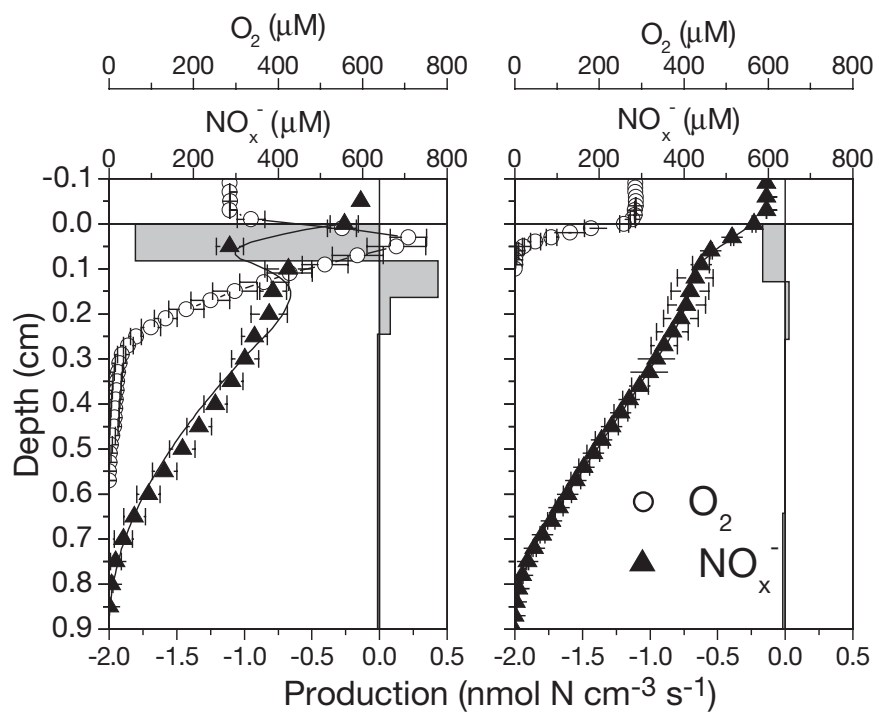

Fig. 3. Porewater profiles of $\mathrm{O}_{2}(\mathrm{O})$ and of $\mathrm{NO}_{\mathrm{x}}{ }^{-}(\boldsymbol{\Lambda})$ and $\mathrm{NO}_{\mathrm{x}}^{-}$ production profiles (gray boxes), measured after $4 \mathrm{wk}$ of incubation in the high-N alga sediment. Line represents modeled profiles. Error bars represent SEM. Note that production/ consumption probably is underestimated (see 'Results')

assimilated in the oxic zone, and there was no indication of net $\mathrm{NO}_{\mathrm{x}}{ }^{-}$production in the sediment. No input of $\mathrm{NO}_{\mathrm{x}}{ }^{-}$to the anoxic sediment strata could therefore be detected. In the low-N alga-free sediment, aerobic net $\mathrm{NO}_{\mathrm{x}}{ }^{-}$production still persisted and $\mathrm{NO}_{\mathrm{x}}{ }^{-}$penetrated almost $2 \mathrm{~mm}$ into the anoxic zone. The average volumespecific rate of $\mathrm{NO}_{3}{ }^{-}$consumption in the anoxic zone was $70 \mathrm{nmol} \mathrm{cm}{ }^{-3} \mathrm{~h}^{-1}$, as inferred from the $\mathrm{NO}_{\mathrm{x}}{ }^{-}$mean profile (Fig. 2). This compares well to the volumespecific $\mathrm{NO}_{3}{ }^{-}$reduction rates measured with isotopes in this sediment (78 $\pm 2 \mathrm{nmol} \mathrm{cm} \mathrm{cm}^{-3} \mathrm{~h}^{-1}$; Fig. 1).

In contrast to the low-N alga sediment, $\mathrm{NO}_{\mathrm{x}}^{-}$ penetrated through the oxic zone of the high-N alga sediment, and a flux into the anoxic zone was observed even after 4 wk of incubation (Fig. 3). $\mathrm{NO}_{\mathrm{x}}{ }^{-}$penetrated $8.5 \mathrm{~mm}$ into the sediment, and the penetration depth was similar in light and darkness. In darkness, the anoxic $\mathrm{NO}_{\mathrm{x}}{ }^{-}$-containing zone spanned approximately $8 \mathrm{~mm}$, whereas it decreased to only $3 \mathrm{~mm}$ during illumination, as photosynthesis and entrapped $\mathrm{O}_{2}$ bubbles expanded the oxic zone to $>5 \mathrm{~mm}$. High rates of $\mathrm{NO}_{\mathrm{x}}{ }^{-}$consumption in the oxic zone of the high-N alga sediments were observed in both light and darkness. This $\mathrm{NO}_{\mathrm{x}}{ }^{-}$consumption zone was located close to the sediment surface in the zone that was photosynthetically active during illumination, and the aerobic $\mathrm{NO}_{\mathrm{x}}{ }^{-}$consumption was therefore ascribed to microphytobenthic N-uptake.

In contrast to the low-N alga sediment (Fig. 2), aerobic $\mathrm{NO}_{\mathrm{x}}{ }^{-}$production was present in the high-N alga sediments, as judged from the results of the numerical profile interpretation (Fig. 3). The profiles measured in darkness indicated a small net $\mathrm{NO}_{\mathrm{x}}{ }^{-}$production in the anoxic zone. A decrease in diffusivity with depth in these deep profiles could explain the apparent deep production zones, and we consider the indication for anaerobic $\mathrm{NO}_{\mathrm{x}}{ }^{-}$production to be an artifact. Anaerobic $\mathrm{NO}_{3}{ }^{-}$reduction rates calculated from porewater profiles of the high-N alga sediments were $<40 \%$ of the rates measured with the isotopes. This discrepancy might suggest that the method used for estimation of diffusivity (i.e. Iversen \& Jørgensen 1993) underestimated actual transport of ions in these thick algal mats. Such an underestimation will lead to underestimation of process rates. We therefore consider the inferred rates as minimum estimates.

\section{Impact of $\mathrm{NH}_{4}{ }^{+}$on $\mathrm{NO}_{\mathrm{x}}{ }^{-}$profiles in low-N alga sediments}

$\mathrm{NO}_{\mathrm{x}}{ }^{-}$porewater profiles measured before and after pulse addition of $\mathrm{NH}_{4}{ }^{+}$to low-N alga sediments incubated for 2 wk are shown in Fig. 4. Addition of $\mathrm{NH}_{4}{ }^{+}$to the water column above this sediment led to net $\mathrm{NO}_{\mathrm{x}}{ }^{-}$ production in the oxic zone upon illumination, and the $\mathrm{NO}_{\mathrm{x}}{ }^{-}$concentration rose to $112 \mu \mathrm{M}$ near the oxic/ anoxic interface within $5 \mathrm{~h}$. The $\mathrm{NO}_{\mathrm{x}}{ }^{-}$porewater profile may not have been in steady state at this moment, and the estimated $\mathrm{NO}_{\mathrm{x}}{ }^{-}$production rate should therefore be considered as a minimum estimate. Yet, the estimated rate was at least as high as the production rate measured in the same sediment after $1 \mathrm{wk}$ of incubation (Fig. 2). Ammonium addition furthermore led to reduction in the rate of $\mathrm{NO}_{\mathrm{x}}{ }^{-}$consumption at the sediment surface, presumably because of preferential $\mathrm{NH}_{4}{ }^{+}$uptake by the algae. There was no indication of aerobic $\mathrm{NO}_{\mathrm{x}}^{-}$production in the dark, even $9 \mathrm{~h}$ after $\mathrm{NH}_{4}{ }^{+}$addition. This was likely caused by $\mathrm{O}_{2}$ limitation of $\mathrm{NO}_{\mathrm{x}}{ }^{-}$production below $1 \mathrm{~mm}$ depth and absence or inhibition of the capacity in the algal layer.

\section{DISCUSSION}

\section{Anammox and denitrification in MPB-colonized sediments}

This study confirms the hypothesis that the anammox capacity of sediments is negatively affected by MPB colonization at low inorganic nitrogen concentrations, while the capacity for denitrification is largely unaffected.

In 2 experimental series, we demonstrated reproducible patterns in the response of anammox and denitrification capacity to MPB colonization. Our data 


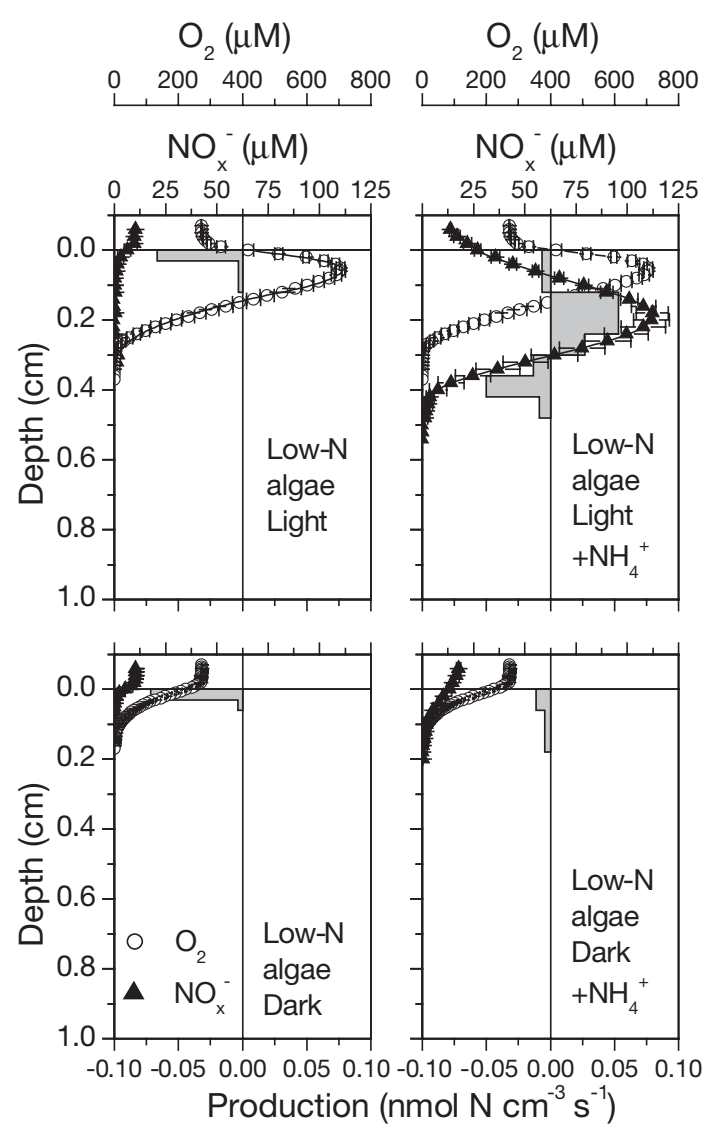

Fig. 4. Porewater profiles of $\mathrm{O}_{2}(\mathrm{O})$ and of $\mathrm{NO}_{\mathrm{x}}{ }^{-}(\mathbf{\Lambda})$ and $\mathrm{NO}_{\mathrm{x}}{ }^{-}$ production profiles (gray boxes) measured before and after pulse addition of $\mathrm{NH}_{4}^{+}$(resulting concentration approximately $1 \mathrm{mM})$. Lines represent modeled profiles. Error bars represent SEM

showed that anammox rates determined after a $3 \mathrm{wk}$ period of algal colonization at low inorganic $\mathrm{N}$ concentrations were significantly lower than initial rates (Fig. 1). The rates obtained from these alga-colonized sediments were also significantly lower than rates obtained from alga-free sediments incubated in darkness at the same $\mathrm{NO}_{3}{ }^{-}$concentration (Table 1, Fig. 1). The rates were measured in the presence of excess $\mathrm{NH}_{4}{ }^{+}$in the sediment slurries, and, since the $\mathrm{NO}_{2}{ }^{-}$concentration was very similar in the slurries prepared from both sediments, we conclude that the observed differences in anammox rates reflect differences in the capacity for anammox in the different types of sediments.

Unlike anammox, the capacity for denitrification was similar in sediments with and without algae incubated at similar $\mathrm{NO}_{3}{ }^{-}$concentrations (Table 1, Fig. 1), which demonstrated that MPB colonization had no negative effect on the denitrification capacity even at low inorganic N concentrations. However, in line with previous results (Risgaard-Petersen 2003), actual denitrification was negatively affected by MPB (Fig. 2).

\section{Factors responsible for MPB-induced reduction of anammox}

Denitrification and anammox are biological processes performed by different species of bacteria in the absence of $\mathrm{O}_{2}$. The decrease in anammox capacity seen in the low-N alga sediment therefore reflects the inability of anammox bacteria to survive or maintain an active enzymatic system under the conditions present in this sediment. The environmental requirements of anammox bacteria and conventional denitrifiers are thus clearly different, as the latter were unaffected by the impacts on their environment imposed by MPB colonization (Table 1, Fig. 1).

The environmental requirements of marine anammox bacteria are unknown, as the organisms have not yet been isolated and characterized. In the present study, we link the potential activity of the $\mathrm{N}_{2}$-producing bacterial community in 3 different systems to metabolically relevant parameters (i.e. $\mathrm{O}_{2}$ and $\mathrm{NO}_{\mathrm{x}}{ }^{-}$) in the microenvironment in which the process would occur. This allows us to formulate a stronger hypothesis as to which factors may be directly responsible for reduction of anammox capacity and maintenance of denitrifying activity during a $4 \mathrm{wk}$ MPB colonization process.

As indicated by the measured porewater profiles (Figs. 2 \& 3), algal colonization had a significant impact on both the $\mathrm{O}_{2}$ and $\mathrm{NO}_{\mathrm{x}}{ }^{-}$concentrations in the sediment. At low water-column $\mathrm{NO}_{3}{ }^{-}$concentration, $\mathrm{NO}_{\mathrm{x}}{ }^{-}$ was almost depleted in the alga-colonized sediments within 2 wk of incubation. The depth distribution of $\mathrm{O}_{2}$ displayed significant variations during the light-dark cycles in both types of alga-colonized sediments, leading to periodical exposure to $\mathrm{O}_{2}$ of sediment strata that may harbor the anammox process (Figs. $2 \& 3$ ). It is clear, however, that periodical exposure of anammox bacteria to $\mathrm{O}_{2}$ was not the main reason for the decrease in their activity in the low- $\mathrm{N}$ alga sediment. Oxygen was present in the upper $5 \mathrm{~mm}$ of the high-N alga sediment during illumination (Fig. 3), and was observed to penetrate to $7 \mathrm{~mm}$ in the preceding weeks (data not shown), yet anammox activity was still preserved (Fig. 1). This suggests that a possible inhibitory effect of $\mathrm{O}_{2}$ was reversible and non-lethal for the organisms, similar to what has been observed for anammox organisms enriched from sewage sludge (Strous et al. 1997).

Nitrogen limitation seems to better explain the decrease in anammox capacity in the alga-colonized sediment incubated at low $\mathrm{NO}_{3}{ }^{-}$concentrations. This sediment exhibited a lack of $\mathrm{NO}_{\mathrm{x}}{ }^{-}$in the anoxic sediment strata after $<2$ wk (Fig. 2), while the $\mathrm{NO}_{\mathrm{x}}{ }^{-}$supply to the anoxic zone and the anammox capacity were preserved in the low- $\mathrm{N}$ alga-free and the high- $\mathrm{N}$ alga sediments (Figs 1 to 3 ). Thus, if marine anammox bacteria base their metabolism solely on $\mathrm{NO}_{2}^{-}$and $\mathrm{NH}_{4}{ }^{+}$ 
conversions, they were deprived of substrates for their energy metabolism to a much higher extent in the low$\mathrm{N}$ alga sediment than in the low- $\mathrm{N}$ alga-free and high$\mathrm{N}$ alga sediments. It should be noted that we have no direct evidence for the presence of $\mathrm{NO}_{2}{ }^{-}$in the high-N alga-free and alga sediment because the applied biosensor measures $\mathrm{NO}_{3}{ }^{-}$and $\mathrm{NO}_{2}{ }^{-}$together (Larsen et al. 1997). However, data from Stief et al. (2002), Rysgaard et al. (2004) and Meyer et al. (2005) show that $\mathrm{NO}_{2}{ }^{-}$may accumulate in sediments through anaerobic $\mathrm{NO}_{3}{ }^{-}$reduction. Given the relatively high concentrations of $\mathrm{NO}_{\mathrm{x}}^{-}$measured in the anoxic zone of these sediments, it is very likely that the measured values were in part due to $\mathrm{NO}_{2}^{-}$.

The change in anammox capacity of the low-N algacolonized sediment may reflect 2 scenarios: (1) the anammox bacteria were inactive due to starvation, and the duration $(4 \mathrm{~h})$ of the slurry incubations did not exceed the lag-phase required for the cells to resume activity; or (2) the cells died following starvation, parallel to what has been observed for aerobic AOBs following MPB-induced N-starvation in a marine sediment (Risgaard-Petersen et al. 2004b). Without pure cultures or recovery experiments of longer duration we cannot distinguish between these possibilities.

In contrast to what we here assume to apply to marine anammox bacteria, most conventional denitrifiers have a versatile metabolism and do not necessarily need $\mathrm{NO}_{\mathrm{x}}{ }^{-}$for energy generation (Zumft 1992). This may explain why denitrifiers were not affected negatively by MPB colonization. Almost all denitrifiers are facultative aerobes and can therefore produce energy in $\mathrm{N}$-deprived algal systems, when photosynthesis leads to deep penetration of $\mathrm{O}_{2}$. Denitrifying bacteria are also known to maintain a capacity for denitrification even after very long periods without exposure to $\mathrm{NO}_{\mathrm{x}}{ }^{-}$, as was demonstrated by Jørgensen \& Tiedje (1993) in studies of the denitrification capacity and abundance of denitrifiers in several permanently anaerobic, $\mathrm{NO}_{\mathrm{x}}{ }^{-}$-free environments.

\section{MPB, anammox and N-limitation}

We attribute the observed shift in anammox capacity of the low-N alga sediment to the ability of the MPB to impede the supply of $\mathrm{NO}_{\mathrm{x}}{ }^{-}$to the anoxic sediment strata during $\mathrm{N}$-limitation. In line with previous studies (e.g. Lorenzen et al. 1998, An \& Joye 2001, RisgaardPetersen 2003, Risgaard-Petersen et al. 2004b), the present study shows that MPB has a significant impact on the availability of $\mathrm{NO}_{\mathrm{x}}{ }^{-}$in the sediment. Algal activity may both enhance and impede $\mathrm{NO}_{\mathrm{x}}^{-}$availability through the opposing impacts on the microbial community of algal $\mathrm{O}_{2}$ production and nutrient assimila- tion. Oxygenic photosynthesis can stimulate nitrification through expansion of the oxic zone, increasing the supply of $\mathrm{NO}_{\mathrm{x}}{ }^{-}$to the anoxic sediment strata compared to alga-free sediments. Such an effect was observed in the present study in the low-N alga sediments after 1 wk of incubation (Fig. 2). Algal N-assimilation may, on the other hand, impede the supply of $\mathrm{NO}_{\mathrm{x}}{ }^{-}$to the anoxic sediment strata due to assimilation of $\mathrm{NO}_{\mathrm{x}}{ }^{-}$diffusing into the sediment from the water column, or inhibition of $\mathrm{NO}_{\mathrm{x}}^{-}$production by nitrification in the sediment (Fig. 2). Inhibition of nitrification is most likely caused by $\mathrm{NH}_{4}{ }^{+}$limitation due to algal assimilation, as indicated further by results of the $\mathrm{NH}_{4}^{+}$ addition experiment performed in the present study (Fig. 4).

The transition from a system in which MPB stimulates $\mathrm{NO}_{\mathrm{x}}{ }^{-}$availability, to a system in which MPB hinders $\mathrm{NO}_{\mathrm{x}}{ }^{-}$availability, is most likely controlled by the overall $\mathrm{N}$-availability in the system. In an $\mathrm{N}$-limited system, such as the low-N alga sediment studied, assimilatory processes may monopolize $\mathrm{N}$-cycling in the surface sediment, leading to inhibition of net $\mathrm{NO}_{\mathrm{x}}^{-}$ production and supply of $\mathrm{NO}_{\mathrm{x}}^{-}$to the anoxic part of the sediment (Fig. 2). In systems with excess N, such as the high-N alga sediment, assimilatory processes will not be able to monopolize the N-cycle (Fig. 3).

The reason why N-limitation can favor MPB assimilation is that MPB has privileged access to $\mathrm{N}$ in the water column (see Fig. 2) and that MPB has higher growth rates and a more efficient $\mathrm{N}$-uptake than AOB (Risgaard-Petersen et al. 2004b).

Nitrogen availability in shallow-water estuaries exhibiting benthic photosynthesis varies in time and space (Nielsen et al. 1995, 2001, Rysgaard et al. 1995, Sundback et al. 2000), and nutrient concentrations in the water column are often low during the summer months, due to reduced discharge from land. During these months, the presence of MPB is likely to negatively affect the supply of $\mathrm{NO}_{\mathrm{x}}{ }^{-}$to the anoxic sediment strata through the mechanisms demonstrated here. This effect of MPB on $\mathrm{NO}_{\mathrm{x}}^{-}$availability has been observed in microsensor studies of natural marine sediments (Meyer et al. 2001, Risgaard-Petersen et al. 2004a) and in numerous studies of denitrification (Rysgaard et al. 1995, Cabrita \& Brotas 2000, Sundback et al. 2000, 2004). Although the present data were generated in experimental systems, the mechanisms demonstrated here are likely to occur in the field.

In the present study we have demonstrated that reduced activity of anammox bacteria in MPB-colonized sediments is most likely linked to the ability of MPB to hinder the supply of $\mathrm{NO}_{\mathrm{x}}{ }^{-}$and thereby the supply of $\mathrm{NO}_{2}^{-}$to the anoxic sediment strata harboring the process. Our data indicate that the ability of MPB to hinder this supply is controlled by the overall availabil- 
ity of $\mathrm{N}$ in the system. On the basis of these results, we suggest that anammox is of very limited significance in environments that periodically experience N-limitation. We therefore expect that anammox in coastal sediments will be most significant in estuaries with constant high concentrations of $\mathrm{NO}_{\mathrm{x}}{ }^{-}$in the water column, such as the Thames estuary, UK (Trimmer et al. 2003), and Randers Fjord, Denmark (Risgaard-Petersen et al. 2004a), or at deeper locations where MPB is absent. However, this has still to be verified through future field studies.

Acknowledgements. We thank Anna Haxen, Kitte Gerlich, Egon Frandsen, Preben Sørensen and Marlene Jessen for assistance in the laboratory. Tage Dalsgaard is thanked for his comments on the manuscript. This study was supported by grants from the Danish Natural Science Research Council, The Carlsberg Foundation and the Foundation for Strategic Environmental Research, Sweden (MISTRA).

\section{LITERATURE CITED}

An SM, Joye SB (2001) Enhancement of coupled nitrification-denitrification by benthic photosynthesis in shallow estuarine sediments. Limnol Oceanogr 46:62-74

Berg P, Risgaard-Petersen N, Rysgaard S (1998) Interpretation of measured concentration profiles in sediment pore water. Linmol Oceanogr 43:1500-1510

Bower CE, Holm-Hansen T (1980) A salicylate-hypoclorite method for determining ammonia in seawater. Can J Fish Aquat Sci 37:794-798

Broecker WS, Peng TH (1974) Gas exchange between air and sea. Tellus 26:21-35

Cabrita MT, Brotas V (2000) Seasonal variation in denitrification and dissolved nitrogen fluxes in intertidal sediments of the Tagus estuary, Portugal. Mar Ecol Prog Ser 202: 51-65

Dalsgaard T (2003) Benthic primary production and nutrient cycling in sediments with benthic microalgae and transient accumulation of macroalgae. Limnol Oceanogr 48: 2138-2150

Dalsgaard T, Canfield DE, Petersen J, Thamdrup B, AcunaGonzalez J (2003) N-2 production by the anammox reaction in the anoxic water column of Golfo Dulce, Costa Rica. Nature 422:606-608

Grasshoff K, Erhardt M, Kremling K (1983) Methods of seawater analysis. Verlag Chemie, Weinheim

Iversen N, Jørgensen BB (1993) Diffusion-coefficients of sulfate and methane in marine sediments - influence of porosity. Geochim Cosmochim Acta 57:571-578

Jørgensen KS, Tiedje JM (1993) Survival of denitrifiers in nitrate-free, anaerobic environments. Appl Environ Microbiol 59:3297-3305

Kuypers MMM, Sliekers AO, Lavik G, Schmid M and 5 others (2003) Anaerobic ammonium oxidation by anammox bacteria in the Black Sea. Nature 422:608-611

Larsen LH, Kjær T, Revsbech NP (1997) A microscale $\mathrm{NO}_{3}{ }^{-}$ biosensor for environmental applications. Anal Chem 69: 3527-3531

Li YH, Gregory S (1974) Diffusions of ions in sea water and in deep-sea sediments. Geochim Cosmochim Acta 38: 703-714

Lorenzen J, Larsen LH, Kjaer T, Revsbech NP (1998) Biosen- sor determination of the microscale distribution of nitrate, nitrate assimilation, nitrification, and denitrification in a diatom-inhabited freshwater sediment. Appl Environ Microbiol 64:3264-3269

Meyer RL, Kjaer T, Revsbech NP (2001) Use of $\mathrm{NO}_{\mathrm{x}}^{-}$ microsensors to estimate the activity of sediment nitrification and $\mathrm{NO}_{\mathrm{x}}{ }^{-}$consumption along an estuarine salinity, nitrate, and light gradient. Aquat Microb Ecol 26:181-193

Meyer RL, Risgaard-Petersen N, Allen DE (2005) Correlation between anammox activity and the microscale distribution of nitrite in a subtropical mangrove sediment. Appl Environ Microbiol (in press)

Nielsen K, Nielsen LP, Rasmussen P (1995) Estuarine nitrogen retention independently estimated by the denitrification rate and mass balance methods: a study of Norsminde Fjord, Denmark. Mar Ecol Prog Ser 119:275-283

Nielsen K, Risgaard-Petersen N, Somod B, Rysgaard S, Bergo $T$ (2001) Nitrogen and phosphorus retention estimated independently by flux measurements and dynamic modelling in the estuary, Randers Fjord, Denmark. Mar Ecol Prog Ser 219:25-40

Revsbech NP (1989) An oxygen microelectrode with a guard cathode. Limnol Oceanogr 34:474-478

Risgaard-Petersen N (2003) Coupled nitrification-denitrification in autotrophic and heterotrophic estuarine sediments: on the influence of benthic microalgae. Limnol Oceanogr 48:93-105

Risgaard-Petersen N, Rysgaard S (1995) Nitrate reduction in sediments and waterlogged soils measured by ${ }^{15} \mathrm{~N}$ techniques. In: Alef K, Nannipieri P (eds) Methods in applied soil microbiology. Academic Press, London, p 287-296

Risgaard-Petersen N, Meyer RL, Schmid M, Jetten MSM, Enrich-Prast A, Rysgaard S, Revsbech NP (2004a) Anaerobic ammonium oxidation in an estuarine sediment. Aquat Microb Ecol 36:293-304

Risgaard-Petersen N, Nicolaisen MH, Revsbech NP, Lomstein BA (2004b) Competition between ammonia-oxidizing bacteria and benthic microalgae. Appl Environ Microbiol 70: 5528-5537

Rysgaard S, Glud RN (2004) Anaerobic $\mathrm{N}_{2}$ production in Arctic sea ice. Limnol Oceanogr 49:86-94

Rysgaard S, Christensen PB, Nielsen LP (1995) Seasonal variation in nitrification and denitrification in estaurine sediment colonized by benthic microalgae and bioturbating infauna. Mar Ecol Prog Ser 126:111-121

Rysgaard S, Glud RN, Risgaard-Petersen N, Dalsgaard T (2004) Denitrification and anammox activity in Arctic marine sediments. Limnol Oceanogr 49:1493-1502

Schmid M, Walsh K, Webb R, Rijpstra W and 11 others (2003) Candidatus Scalindua brodae sp. nov., candidatus Scalindua wagneri sp. nov.: two new species of anaerobic ammonium oxidizing bacteria. Syst Appl Microbiol 26: $529-538$

Schmidt I, Sliekers O, Schmid M, Cirpus I, Strous M, Bock E, Kuenen JG, Jetten MSM (2002) Aerobic and anaerobic ammonia oxidizing bacteria competitors or natural partners? FEMS Microbiol Ecol 39:175-181

Sømod B, Ellegaard C, Hansen DF, Jensen CA (2003) Vestlige kattegat og tilstødende fjorde 2002. Tilstand og udvikling, Randers Fjord, County of Nordjylland and County of Aarhus, p 47-71

Stief P, De Beer D, Neumann D (2002) Small-scale distribution of interstitial nitrite in freshwater sediment microcosms: the role of nitrate and oxygen availability, and sediment permeability. Microb Ecol 43:367-378

Strous M, vanGerven E, Kuenen JG, Jetten M (1997) Effects of aerobic and microaerobic conditions on anaerobic 
ammonium-oxidizing (Anammox) sludge. Appl Environ Microbiol 63:2446-2448

Strous M, Fuerst JA, Kramer EHM, Logemann S and 5 others (1999a) Missing lithotroph identified as new planctomycete. Nature 400:446-449

Strous M, Kuenen JG, Jetten MSM (1999b) Key physiology of anaerobic ammonium oxidation. Appl Environ Microbiol 65:3248-3250

Sundback K, Miles A, Goransson E (2000) Nitrogen fluxes, denitrification and the role of microphytobenthos in microtidal shallow-water sediments: an annual study. Mar Ecol Prog Ser 200:59-76

Sundback K, Linares F, Larson F, Wulff A, Engelsen A (2004) Benthic nitrogen fluxes along a depth gradient in a microtidal fjord: the role of denitrification and microphytobenthos. Limnol Oceanogr 49:1095-1107

Editorial responsibility: Søren Rysgaard, Silkeborg, Denmark
Thamdrup B, Dalsgaard T (2002) Production of N-2 through anaerobic ammonium oxidation coupled to nitrate reduction in marine sediments. Appl Environ Microbiol 68: $1312-1318$

Trimmer M, Nicholls JC, Deflandre B (2003) Anaerobic ammonium oxidation measured in sediments along the Thames Estuary, United Kingdom. Appl Environ Microbiol 69:6447-6454

van de Graaf AA, de Bruijn P, Robinson LA, Jetten MSM, Kuenen JG (1996) Autotrophic growth of anaerobic ammonium-oxidizing microorganisms in a fluidized bed reactor. Microbiology 142:2187-2196

Zumft WG (1992) The denitrifying prokaryotes. In: Balows A (ed) The prokaryotes: a handbook on the biology of bacteria: ecophysiology, isolation, identification, applications. Springer, Heidelberg, p 554-582

Submitted: February 8, 2005; Accepted: May 8, 2005

Proofs received from author(s): June 28, 2005 